\title{
磯辺俊彦著 \\ 『むらと農法変革一「市場モデル」から「むらモデル」へ』
}

東京農業大学出版会 2010 年 11 月

\section{安藤 光義}

磯辺氏の著作はどれも難解で評者の理解の及ぶと ころではないため、当初、この書評は辞退する予定 だったが、『日本農業の土地問題』での経験一一読む 者の読み方次第で豊穣な実りを得られる肥沃な大地 であった——ことを思い起こし、久しぶりに慣れな い鋤を手に取った次第である。これを言い訳として、 著者の本来の意図とは異なるとは思うが、評者の感 じたところを忌憚なく述べさせて頂く。

第 I 部「これまで一 sein としての農法変革一」は 第 1 章「明治農法の形成とその担い手たち」第 2 章「農 政浸透機構の整備と農事改良の進展」、第 3 章「いわ ゆる『佐賀段階』の形成過程」の 3 章から構成される。

「古墓錅為田、松柏摧為薪」。最初の 2 つの章を読 んだ評者の頭に浮かんだのはこの言葉であった。明 治前期の「技術革新の担い手、新農法形成の推進者」 であり、「その実現のための社会経済的条件の整備・ 改革の推進者であった」老農の活躍は、「明治農法の 形成・定着として結実し農民層の新たな蓄積の可能 性を生み出していくのであるが、しかもそのことに 依拠した寄生地主制の拡大・確立を現実には生み出 していき、そこで農民層の蓄積の条件は新たなレべ ルで奪われ」る結果となってしまう過程を描いた第 1 章。「明治農法形成という新しい契機によって促され た旧慣変革的な、そのかぎりすぐれて経済合理性を 意識した機能組織であった」農家小組合は「集団的 生産力の形成を求める農法変革の主体的エネルギー・ 前向きの根性を内包した、すぐれて開かれた」存在 であったが、次第に変質を始めて農政浸透の末端組 織となり、さらには「戦時体制下の共同精神を前面 に押しだした統制的な『閉ざされた集落』に大きく 右旋回して」いってしまう。だが、「零細農耕制のも とで米作偏重の農法の形成が進むなか」そそうした制 約条件の枠内ではあるが、経営上昇の道筋を切り開 いていったのが自小作農であった（第 2 章）。第 3 章 ではその典型として佐賀平坦の姿が描かれる。

「幸福は達成できた幸福のなかにあるというより も、幸福になろうとこころざして努めている意志の なかにこそ幸福はみつかる」(島崎敏樹『生きるとは 何か』)。「その豊沃な土堛に立脚しつつ、機械灌溉・
干拓等の米作主産地化条件の形成のための社会的投 資によって支えられた農業生産力の進展と、他方 で寄生地主の倒産による土地購入への個別的投資に よって谹制された農民経済の動摇・不安定との、こ の 2 面によって表示せられている」とする「佐賀段 階」のみごとな総括以上に、「低価格・安定のもとで の量産主義」という歪みを有しながらもささやかな 幸せを信じて「佐賀段階」を確立した農民の歩みを、 外部制約条件と関連づけながら丹念に叙述した点に 第 3 章の魅力はあるように思う。ミセス・フランク は学問的作法に則ってスパイラルな内生的な成果の 累積過程を示したが、描かれているのはそれを推し 進めた人間の姿ではなかっただろうか。著者の言葉 を借りれば「村落組織は、以前よりも均質な農民層 の相互的な組織として再生され、そのかぎりで、む しろ強められさえした」のであり、社会資本投資と しての労働節約的技術の導入は「『労働集約的』な新 技術体系の累積的な形成を、個々の農民層にもたら し」「しかも、その過程が、同時にその新技術の担 い手としての自小作型の中農層の支配的な成長過程 でもあった」ということになるだろう。この佐賀平 坦で描かれた農民の姿に込められた人間の前に進も うとする内発的な主体的な意志こそ、第 II 部「これ から一 sollen としての農法変革一」を貫く 1つのモ チーフであるように思う。

第 4 章「ひとびとの跫音一変革の担い手たちのラ イフ・ヒストリ」は、「人間の『詩』の優しさは、人 生の失意と憂愁と諦念から由来するものであっても、 最後の一線で人間の美しさを支えようとする気魄な のであり、ひたすらに生きることが必要なのであろ う」(霜山徳爾『人間の詩と真実』) という一節を私 に想い起こさせてくれた。これは経済学ではないか もしれないが、確かに「人間の詩と真実」だと思う。 「自分の足ですすむとき、まわりの世界はたしかにそ こに実在する世界となるし、自分もたしかにそのと き生きていたあかしを得るのである」(島崎敏樹『孤 独の世界』）ということかもしれない。第 4 章は本書 の「間奏曲」として受け止めた。

第 5 章「コモンズという言葉で何が言いたいの 
か?」は一気に転調し、強い調子で「古墓」「松柏」 の声が奏でられる。去りゆく現代の老農の叫びと いったら叱られるだろうか。歴史認識の欠如したコ モンズ論はコモンズ論に值しない。コモンズが「自 然環境や自然資源を持続可能な形で利用・管理・維 持するための制度・組織」にすぎないとすれば、そ れをわざわざ社会科学として議論する必要はどこに あるのだろうか。そこには「人間の詩と真実」はな い。人間の血が通っていない共同体をコモンズとい い換えて、これまで積み重ねてきた営為をすきくだ かれてしまっては堪まったものではない。だったら 社会工学として論ずればよいではないか。これまで 蓄積されてきた「むら」論の諸論点はコモンズとい う名のボロを被せられて消えてしまう。「新奇だが、 それを社会科学の発展といってよいのであろうか」。 これと同様の批判は「期待されるグローバルなマル テチュード」に対しても向けられる。「大地に足を踏 まえた『主体形成』の歴史的把握がどうしても必要」 なのである。それゆえ「それぞれの地域に即した community の歴史的性格を十分に吟味」することが 不可欠であって、「その地域が、どのような慣行的行 動にもとづいて環境破壊を防ごうとしているか、そ こでの歴史条件と風土条件に即した地域資源管理の 秩序のありようを見ていくべき」なのである。そして、 その秩序が生まれてくるプロセスは、かつての「佐 賀段階」が形成された時のように「スパイラルな内 生的な成果の累積過程」となるはずである。コモン ズを論じようとするのであれば、そのようなものと して描いてもらえないだろうか。これでは死んでも 死にきれない。かなり筆が滑ってしまったが、「諦念」 の境地に達していない評者が第 5 章を引き継いだな らば、このように書いていたかもしれない。

共同体について 1 点だけ確認しておこう。共同体 は出入り自由なオープンなものではなく、その背後 には何らかの「専有された独占的権益」が存在して いる。そして、この「専有化とは、独占化された社 会的あるいは経済的権益が、内部に対しても、つま り同一成員に対しても『閉鎖化』されることである。 この過程は、原則としてあらゆるケースを同じょう に貫徹している。異なっているのは押し進められる 際の難易のみである」(マックス・ウェーバー「経済 と社会集団」『世界の名著 81 ウェーバー』中央公 論社、1979、534-535 頁)。もし、共同体をこのよう に理解したとすれば、程度の如何は別として、共同 体の内部は構造化されており、そこには差異、序列、 場合によっては差別すら内包されているということ
になるのではないだろうか。共同体を論じるに際し ては外部との関係だけでなく、内部の構造にも注意 を払う必要があるのである。

「国民国家の基本の内部矛盾を国民自ら止揚するこ となしに、直ちに人々は脱国家的な『期待されるグ ローバルなマルテチュード』たりえないだろう」と いう視座から、日本農業のあるべき姿を描いたのが 第 6 章「日本農業再構築の課題」と第 7 章「日本農 法変革への基本論理一家族制農業と「むら」」であ る。状況認識は同じであり、とくに付け加えるべき ことはないが、あえて波風を立てるべく「田畑輪換」 「高度水田利用」「深耕精作」をあるべき農法として 措定することは妥当かどうか問題を投げかけておく。 これは中島紀一による加用農法論への異議申し立て (「耕作放棄地の意味と新しい時代における農地論の 組み立て試論」農業問題研究学会編『土地の所有と 利用』）にどう答えたらよいかということでもある。

第 8 章の「村落共同体論・雑考一『豊原村』『善 治日誌』からみた」に対するコメントは 2 点ある。1 点目は、「どこの村にもさまざまの形である差別の構 造を農村社会把握の基本論理のなかにとりこんでい く」必要があり、「この認識とその社会主体的な止 揚の途筋の模索がないかぎり、むら共同体の論理は、 所詮は体制肯定の枠を超えることはできない」(『日 本農業の土地問題』）ことを前提に、「庄内では、こ の直系家族から外れた次三男・水吞・名子など旧村 内にいた従属百姓が大量に開発新田（沖郷）に吸収 されていき、開発地主の収奪のもとにおかれ、結果 として残された古田地帯 (沢郷) では村ごとに戸数 の変わら妋婦家族経営が対等な百姓仲間として一 般化されていった」という事態を理解しようとすれ ば、豊原村は非常に特殊な村であり、これを一般化 することはできないということである。差別がある から構造があり、その構造が安定的に保たれるので ある。そして、その背後には何らかの「専有された 独占的権益」がなくてはならない。これが 2 点目で あり、現代の農村に敷衍すれば、「あとつぎ他出規範」 (小田切徳美) の下で子供たちは村を去り、米価は暴 落して農地は不良債権化し、「権益」どころか「重荷」 しか残されていない空洞化した農村となったからこ そ、差別も構造もなくなり、新しい農村社会が生ま れようとしているようにも評者にはみえるのである。

幾つかの挑発は「やることがなくなっても、詮な いこと」にならないようにするためのものだと理解 して頂けると幸いである。妄言多謝。

(東京大学) 